Zeszyty Naukowe Szkoły Głównej Gospodarstwa Wiejskiego w Warszawie

Problemy Rolnictwa Światowego tom 18 (XXXIII), zeszyt 1, 2018: 38-47

DOI: 10.22630/PRS.2018.18.1.3

Agnieszka Biernat-Jarka ${ }^{1}$, Paulina Trębska ${ }^{2}$

Szkoła Główna Gospodarstwa Wiejskiego w Warszawie

\title{
Ubóstwo w Polsce i Unii Europejskiej a formy jego przezwyciężania w kontekście zrównoważonego rozwoju i doświadczeń UE
}

\section{Poverty in Poland and the European Union and the Forms of Overcome it, in the Context of Sustainable Development and the EU Experience}

\begin{abstract}
Synopsis. Celem artykułu jest ocena zjawiska ubóstwa w Polsce na tle innych krajów Unii Europejskiej oraz scharakteryzowanie wybranych form przezwyciężania ubóstwa w kontekście zrównoważonego rozwoju. W artykule dokonano przeglądu literatury z tego obszaru oraz analizy źródeł wtórnych pochodzących z Głównego Urzędu Statystycznego i EUROSTAT. Ubóstwo jest zjawiskiem powszechnym i występuje we wszystkich krajach Unii Europejskiej. Około 17\% obywateli Unii Europejskiej jest zagrożonych ubóstwem. Problem ten powinien być rozwiązany ze względu na zrównoważony i trwały rozwój i jest to podstawą europejskiej strategii walki z ubóstwem i wykluczeniem społecznym.
\end{abstract}

Słowa kluczowe: zrównoważony rozwój, ubóstwo, wskaźnik zagrożenia ubóstwem, walka z biedą

\begin{abstract}
The aim of this article is to assess the forms of overcoming poverty in Poland against the background of the European Union in the context of sustainable development and the experience of the European Union. The article presents the scale of poverty in Poland and in the European Union, reviewing literature from this area and analysis of secondary sources from the Central Statistical Office and EUROSTAT.
\end{abstract}

Key words: sustainable development, poverty, the indicator of the risk of poverty, the fight against poverty

JEL Classification: I32, P46, Q01

\section{Wprowadzenie}

Zrównoważony rozwój jest zagadnieniem bardzo szerokim. Ekonomia zrównoważonego rozwoju rozwija się na filozoficznej podbudowie idei zrównoważonego rozwoju z wykorzystaniem dorobku ekonomik cząstkowych, tj. ekonomii środowiska, ekonomii ekologicznej, ekonomii instytucjonalnej, ekonomii społecznej i innych (Poskrobko, 2011). Ekonomia zrównoważonego rozwoju nawiązuje do filozofii ekologicznej i ekologii społecznej, gdzie dowiedziono, że powinnością człowieka jest takie

\footnotetext{
${ }^{1}$ dr inż., Katedra Polityki Europejskiej i Marketingu, Wydział Nauk Ekonomicznych SGGW, ul. Nowoursynowska 166,02-787 Warszawa, e-mail: agnieszka_biernat_jarka@sggw.pl, https://orcid.org/0000-0003-2497-1656

${ }^{2}$ mgr, e-mail: paulina_trebska@sggw.pl, https://orcid.org/0000-0002-0364-4296.
} 
gospodarowanie środowiskiem przyrodniczym, aby zachować podstawy życia i rozwoju zarówno współczesnych, jak i przyszłych pokoleń (Piątek, 2010).

Zasadę zrównoważonego rozwoju uznano w Polsce za problem tak ważny, że została ona wpisana do 5 art. Konstytucji RP „Rzeczpospolita Polska (...) strzeże dziedzictwa narodowego oraz zapewnia ochronę środowiska, kierując się zasadą zrównoważonego rozwoju" (Konstytucja RP, Dz. U. 1997, nr 78, poz. 483).

Za jedną z najtrafniejszych polskich definicji zrównoważonego rozwoju można uznać definicję zawartą w ustawie Prawo ochrony środowiska (Dz. U. $2001 \mathrm{nr} 62$ poz. 627), według której jest to: „rozwój społeczno-gospodarczy, w którym następuje proces integrowania działań politycznych, gospodarczych i społecznych, $\mathrm{z}$ zachowaniem równowagi przyrodniczej oraz trwałości podstawowych procesów przyrodniczych, w celu zagwarantowania możliwości zaspokajania podstawowych potrzeb poszczególnych społeczności lub obywateli zarówno współczesnego pokolenia, jak i przyszłych pokoleń" (Ustawa Prawo Ochrony Środowiska, Dz. U. 2001, nr 62, poz. 627).

Koncepcja zrównoważonego rozwoju tworzy spójną podstawę dla analizy i praktycznego rozwiązywania problemów społecznych, ekonomicznych i ekologicznych. Polega on na takim kształtowaniu polityki społeczno-gospodarczej, aby obok wartości stricte ekonomicznych uwzględniać także cele społeczne i ekologiczne. Wiąże się to z realizacją trzech zagadnień. Pierwsze to sprawiedliwość społeczna - wzrost gospodarczy musi służyć rozwojowi społecznemu, prowadzić do społecznego dobrobytu (m.in zmniejszając rozwarstwienie społeczne, przeciwdziałając marginalizacji i dyskryminacji). Drugie skupia się na minimalizacji generowanych przez gospodarkę „kosztów zewnętrznych", a trzecie na trosce o bezpieczeństwo obecnego i przyszłych pokoleń. Rozwój zrównoważony polega więc na wprowadzaniu „ładu zintegrowanego”, który rozumie się jako sumę porządków: ekologicznego, społecznego oraz ekonomicznego. (często dodawane są jeszcze dwa łady: przestrzenny oraz instytucjonalno-polityczny).

We współczesnym świecie w wymiarze ekonomicznym pogłębia się obszar ubóstwa. Dramatycznie rozszerzają się dysproporcje w poziomie dobrobytu i jakości życia w skali globalnej, jak również lokalnej. Konsekwencje wywołanego przez banki i inne instytucje finansowe kryzysu ekonomicznego obciażaja budżety wszystkich państw świata i bezpośrednio lub pośrednio - znaczący odsetek budżetów gospodarstw domowych w skali globalnej. Wzrasta zadłużenie państw, społeczności lokalnych oraz poszczególnych gospodarstw domowych wywoływane brakiem równowagi w rozwoju gospodarczym, koniecznościa sprostania rozbudowanym oczekiwaniom i inwestycjom czy nadmiernym konsumpcjonizmem.

Zjawisko biedy rozumiane jest jako niedostatek środków pieniężnych i dóbr materialnych oraz usług pozwalających zaspokoić podstawowe potrzeby człowieka i członków jego rodziny, połączony $\mathrm{z}$ brakiem perspektyw zmiany sytuacji w przewidywalnej przyszłości. Zjawisko to przyjmuje różne postacie, od niedostatku aż po skrajne ubóstwo. Jest zjawiskiem istniejącym nie tylko w krajach słabo rozwiniętych, ale również bogatych, chociaż w tych ostatnich przyjmuje nieco inny poziom i formy. Zmienia się także obraz biedy. Coraz częściej na koncepcję biedy składaja się, poza brakiem dochodów i dóbr materialnych oraz usług, brak pracy czy innych źródeł utrzymania, a także brak perspektyw na przyszłość. Cześciej dołącza się również do obrazu biedy różnorodne wykluczenia społeczne, w tym podstawowe dla współczesnego społeczeństwa wykluczenie informacyjne. W efekcie bieda nabiera charakteru trwałego, wręcz międzypokoleniowego (Czaja, Becla, 2011). 
Powstało wiele definicji ubóstwa, jednak wszystkie one posiadają wspólny element, który mówi, że ubóstwo jest związane z brakiem możliwości zaspokojenia pewnych potrzeb na pożądanym poziomie. Niektórzy autorzy podkreślaja, że w świadomości społecznej ubóstwo jest rozumiane jako brak dostatecznych środków do życia, bieda czy niedostatek (Ratyński, 2003). Najogólniej ubóstwo można zdefiniować jako stan poniżej pewnego zmiennego $\mathrm{w}$ czasie progu dochodowego lub progu realizacji potrzeb w odniesieniu do jednostki, rodziny lub grupy społecznej (Toczyski, 1991).

Działania mające na celu ograniczenie ubóstwa i wykluczenia społecznego stanowią, obok działań nakierowanych na wspieranie zrównoważonego rozwoju gospodarczego i zatrudnienia, jeden z głównych obszarów zainteresowania i zarazem wsparcia Komisji Europejskiej, które znalazły odzwierciedlenie również w głównych celach Strategii Europa 2020. Unia Europejska, jako jeden z podstawowych celów w obszarze integracji społecznej postawiła sobie ,wyprowadzenie” z ubóstwa 20 milionów Europejczyków do $2020 \mathrm{r}$.

Na 70. Sesji Zgromadzenia Ogólnego Narodów Zjednoczonych, obradującej w dniach 25-27 września 2015 r. w Nowym Jorku z udziałem 100 przedstawicieli państw, szefów rządów i liderów społeczeństwa obywatelskiego, przyjęta została „Agenda na rzecz Zrównoważonego Rozwoju 2030”, wskazująca siedemnaście Celów Zrównoważonego Rozwoju, do osiąnnięcia których społeczność międzynarodowa powinna dążyć w ciągu najbliższych piętnastu lat. Każdemu z celów towarzyszy od kilku do kilkunastu zadań, od realizacji których zależy sukces w osiagnięciu poszczególnych celów. Cel pierwszy wskazuje na wyeliminowanie ubóstwa, we wszelkich jego formach, na całym świecie.

\section{Materiał i metody}

Materiał źródłowy badań stanowiły dane statystyczne Głównego Urzędu Statystycznego i EUROSTAT. Celem artykułu jest ocena form przezwyciężania ubóstwa w Polsce na tle Unii Europejskiej w kontekście zrównoważonego rozwoju i doświadczeń Unii Europejskiej. W artykule scharakteryzowano skalę ubóstwa w Polsce i w Unii Europejskiej.

W Strategii Europa 2020 przyjęto, że podstawowym wskaźnikiem służącym monitorowaniu postępów w realizacji działań nakierowanych na walkę z ubóstwem lub wykluczeniem społecznym będzie złożony miernik, uwzględniający trzy wskaźniki cząstkowe. Ponieważ jest on liczony w oparciu o dane zebrane $z$ badania EU-SILC, możliwe jest monitorowanie skutków podjętych w tym zakresie działań na poziomie europejskim oraz krajowym. W związku z tym, wskaźnik zagrożenia ubóstwem lub wykluczeniem społecznym definiowany jest jako odsetek osób zagrożonych ubóstwem relatywnym lub pogłębioną deprywacją materialną lub żyjących w gospodarstwach domowych o bardzo niskiej intensywności pracy. Osoba, która wchodzi w skład gospodarstwa domowego doświadczającego przynajmniej jednego z trzech powyższych elementów, jest więc uważana za zagrożoną ubóstwem lub wykluczeniem społecznym. Należy przy tym zaznaczyć, że osoby zliczane są tylko raz, również w przypadku, gdy zagrożone są więcej niż jedną formą ubóstwa lub wykluczenia społecznego (Międzyresortowy Zespołu ds. Strategii 2020, 2016).

Według wspólnie uzgodnionej przez kraje członkowskie Unii Europejskiej i przyjętej przez Eurostat metodologii, za zagrożone ubóstwem uważa się osoby żyjące w gospodarstwach domowych, których dochód do dyspozycji jest niższy od granicy 
ubóstwa ustalonej na poziomie $60 \%$ mediany dochodu w danym kraju. Przyjęto więc relatywne podejście do pomiaru ubóstwa, zgodnie z którym próg ubóstwa powiązany jest ze standardem życia $w$ poszczególnych krajach. Miara ta określa zatem grupę ludności będącą $\mathrm{w}$ każdym $\mathrm{z}$ krajów $\mathrm{w}$ relatywnie najtrudniejszej sytuacji dochodowej (bez odniesienia do poziomu dochodów w pozostałych państwach) (Szukiełojć-Bieńkuńska, 2008).

\section{Wynik badań}

Ubóstwo we współczesnej Europie jest uznawane za jeden z najpoważniejszych problemów społecznych (Sutkowska, Kandefer, 2013). Z aktualnie dostępnych szacunków Eurostatu przeprowadzonych na podstawie EU-SILC, w którym to badaniu zbierano informacje o sytuacji dochodowej gospodarstw domowych w 2015 r. wynika, że w sferze ubóstwa relatywnego żyło w tym czasie 17,3\% obywateli Unii Europejskiej. W Polsce wskaźnik zagrożenia ubóstwem relatywnym był zbliżony do średniej unijnej i wyniósł $17,6 \%$.

Tabela 1. Wskaźnik zagrożenia ubóstwem lub wykluczeniem społecznym w Polsce i w Unii Europejskiej w latach 2008-2015

Table 1. Poverty risk or social exclusion indicator in Poland and in the European Union in 2008-2015

\begin{tabular}{|c|c|c|c|c|}
\hline \multirow{3}{*}{ Nazwa wskaźnika } & \multirow{3}{*}{ Państwa } & \multicolumn{3}{|c|}{ Lata } \\
\hline & & 2008 & 2014 & 2015 \\
\hline & & \multicolumn{3}{|c|}{ \% osób w gospodarstwach domowych } \\
\hline \multirow{2}{*}{$\begin{array}{l}\text { Wskaźnik zagrożenia ubóstwem } \\
\text { relatywnym }\end{array}$} & Polska & 16,9 & 17,0 & 17,6 \\
\hline & Unia Europejska & 16,5 & 17,2 & $17,3^{*}$ \\
\hline \multirow{2}{*}{$\begin{array}{l}\text { Wskaźnik pogłębionej deprywacji } \\
\text { materialnej }\end{array}$} & Polska & 17,7 & 10,4 & 8,1 \\
\hline & Unia Europejska & 8,5 & 8,9 & $8,1^{*}$ \\
\hline \multirow{2}{*}{$\begin{array}{l}\text { Wskaźnik bardzo niskiej intensywności } \\
\text { pracy w gospodarstwie domowym }\end{array}$} & Polska & 8,0 & 7,3 & 6,9 \\
\hline & Unia Europejska & 9,2 & 11,2 & $10,5^{*}$ \\
\hline \multirow{2}{*}{$\begin{array}{l}\text { Wskaźnik zagrożenia ubóstwem lub } \\
\text { wykluczeniem społecznym }\end{array}$} & Polska & 30,5 & 24,7 & 23,4 \\
\hline & Unia Europejska & 23,7 & 24,4 & 23,7 \\
\hline
\end{tabular}

*dane szacunkowe

Źródło: GUS, Eurostat.

Najniższy wskaźnik zagrożenia ubóstwem lub wykluczeniem społecznym w 2015 roku odnotowano w Czechach, Szwecji, Danii i Francji, natomiast najwyższy poziom w Bułgarii i Rumunii. Problem ubóstwa dotyczy coraz liczniejszych grup społecznych. Kwestia narastającego ubóstwa stała się kwestią społeczną, ubóstwo bowiem stało się elementem egzystencji grup społecznych. Jest to zatem o tyle groźne zjawisko, że ma wpływ na rozwój społeczny kraju. Z badania budżetów gospodarstw domowych wynika, iż w 2016 r. nastąiła wyraźna poprawa sytuacji gospodarstw domowych w Polsce, co znalazło odzwierciedlenie w znaczącym zmniejszeniu się zasięgu ubóstwa. 
Tabela 2. Osoby zagrożone ubóstwem lub wykluczeniem społecznym w UE, 2008 i 2015

Table 2. Persons at risk of poverty or social exclusion in the EU, 2008 and 2015

\begin{tabular}{|c|c|c|c|c|}
\hline \multirow{2}{*}{ Państwa } & \multicolumn{2}{|c|}{$\%$ całkowitej populacji } & \multicolumn{2}{|c|}{ w tysiącach } \\
\hline & 2008 & 2015 & 2008 & 2015 \\
\hline UE* & 23,7 & 23,7 & 115910 & 118760 \\
\hline Belgia & 20,8 & 21,1 & 2190 & 2340 \\
\hline Bułgaria & 44,8 & 41,3 & 3420 & 2980 \\
\hline Czechy & 15,3 & 14,0 & 1570 & 1440 \\
\hline Dania & 16,3 & 17,7 & 890 & 1000 \\
\hline Niemcy & 20,1 & 20,0 & 16340 & 16080 \\
\hline Estonia & 21,8 & 24,2 & 290 & 310 \\
\hline Irlandia & 23,7 & $\#$ & 1050 & \# \\
\hline Grecja & 28,1 & 35,7 & 3050 & 3830 \\
\hline Hiszpania & 23,8 & 28,6 & 10790 & 13180 \\
\hline Francja & 18,5 & 17,7 & 11150 & 11050 \\
\hline Chorwacja & $\#$ & $\#$ & \# & \# \\
\hline Włochy & 25,5 & 28,7 & 15080 & 17470 \\
\hline Cypr & 23,3 & 28,9 & 180 & 240 \\
\hline Łotwa & 34,2 & 30,9 & 740 & 610 \\
\hline Litwa & 28,3 & 29,3 & 910 & 860 \\
\hline Luksemburg & 15,5 & 18,5 & 70 & 90 \\
\hline Węgry & 28,2 & 28,2 & 2790 & 2730 \\
\hline Malta & 20,1 & 22,4 & 80 & 90 \\
\hline Holandia** & 14,9 & 16,8 & 2430 & 2810 \\
\hline Austria & 20,6 & 18,3 & 1700 & 1550 \\
\hline Polska & 30,5 & 23,4 & 11490 & 8760 \\
\hline Portugalia & 26,0 & 26,6 & 2760 & 2760 \\
\hline Rumunia & 44,2 & 37,3 & 9110 & 7430 \\
\hline Słowenia & 18,5 & 19,2 & 360 & 380 \\
\hline Słowacja & 20,6 & 18,4 & 1110 & 960 \\
\hline Finlandia & 17,4 & 16,8 & 910 & 900 \\
\hline Szwecja & 14,9 & 16,0 & 1370 & 1560 \\
\hline Wielka Brytania & 23,2 & 23,5 & 14070 & 15030 \\
\hline
\end{tabular}

* Dane dla 2008 roku nie zawierają Chorwacji. Dane dla 2015 roku są szacunkowe.

** Dane dla 2015 roku są prowizoryczne.

\# Dane nie są dostępne.

Źródło: Eurostat, http://ec.europa.eu/eurostat/documents/2995521/7695750/3-17102016-BP-EN.pdf/30c2ca2df7eb-4849-b1e1-b329f48338dc.

W 2016 r. w przypadku stopy ubóstwa skrajnego oraz stopy ubóstwa relatywnego zaobserwowano znaczące spadki wartości wskaźników w odniesieniu do roku poprzedniego. Wartości obu tych wskaźników spadły rok do roku o 1,6 pkt. proc., przy czym w gospodarstwach domowych o wydatkach poniżej granicy ubóstwa skrajnego żyło 
w 2016 r. ok. 5\% osób w Polsce, natomiast poniżej relatywnej granicy ubóstwa - ok. 14\%. Stopa ubóstwa ustawowego pozostała na poziomie zbliżonym do obserwowanego $\mathrm{w}$ ciągu ostatnich 4 lat, osiaggając w 2016 r. ok. 13\% (GUS, 2017).

Obserwowany w 2016 r. spadek ubóstwa skrajnego dotyczył zdecydowanej większości branych pod uwagę grup ludności, przy czym najbardziej znaczącą poprawę w tym zakresie odnotowano wśród dzieci w wieku 0-17 lat, rodzin wielodzietnych, tj. małżeństw z 3 dzieci na utrzymaniu oraz małżeństw z 4 i większą liczbą dzieci na utrzymaniu, w gospodarstwach $\mathrm{z}$ głową gospodarstwa posiadającą wykształcenie co najwyżej gimnazjalne oraz zasadnicze zawodowe, wśród rolników, a także wśród mieszkańców wsi i małych miast, o liczbie ludności nieprzekraczającej 20 tys. Mimo istotnych spadków stopy ubóstwa w wymienionych powyżej grupach, wciąż należały one do najbardziej zagrożonych ubóstwem skrajnym.

Podobny poziom ubóstwa w 2016 r. w stosunku do roku poprzedniego zaobserwowano natomiast $\mathrm{w}$ gospodarstwach domowych bez dzieci na utrzymaniu, w gospodarstwach z głową gospodarstwa posiadającą wykształcenie wyższe, a także wśród mieszkańców największych miast, o liczbie ludności wynoszącej co najmniej 500 tys. Należy jednak zauważyć, iż obserwowana stopa ubóstwa w tych grupach należała do relatywnie najniższych.

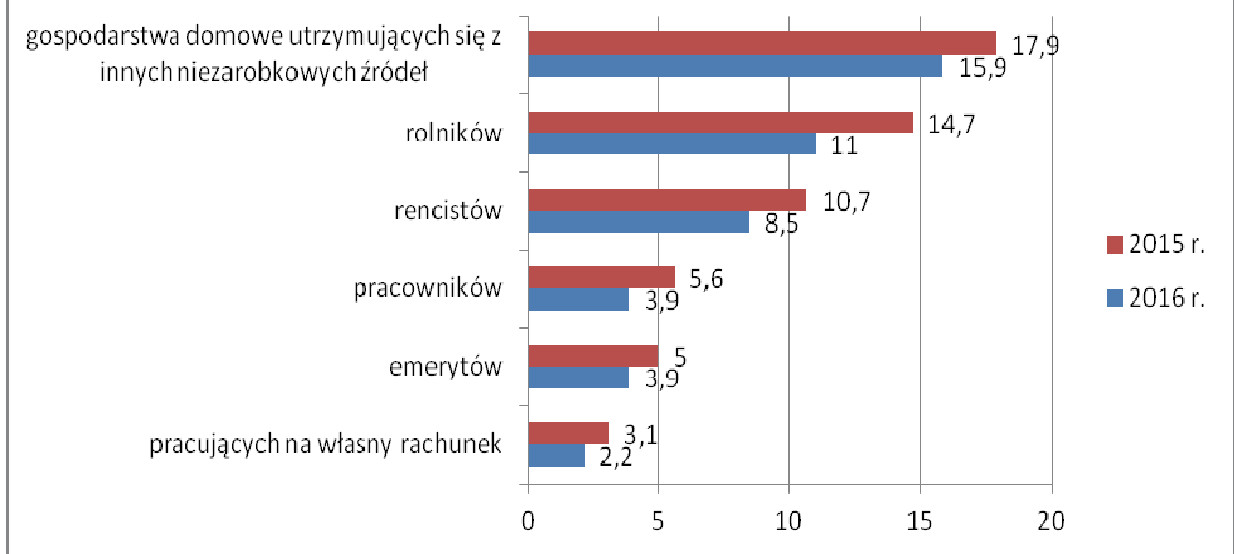

Rys. 1. Zasięg ubóstwa skrajnego w latach 2015-2016 (w \% osób) w gospodarstwach domowych wg grup społeczno-ekonomicznych

Fig. 1. Extent of poverty in 2015-2016 (in \%) in households by socio-economic groups

Źródło: GUS, Badanie Budżetów Gospodarstw Domowych, 2017.

Zasięg ubóstwa jest wyraźnie zróżnicowany w zależności od grupy społecznoekonomicznej, określanej na podstawie przeważającego źródła dochodów. W najtrudniejszej sytuacji znajdowały się osoby żyjące w gospodarstwach domowych utrzymujących się z tzw. innych niezarobkowych źródeł (stopa ubóstwa skrajnego na poziomie ok. 16\%), w tym przede wszystkim w gospodarstwach, których podstawę utrzymania stanowiły świadczenia społeczne inne niż renty i emerytury (ok. 19\%). Bardziej niż przeciętnie narażeni na ubóstwo byli członkowie gospodarstw domowych rolników (11\%) oraz gospodarstw utrzymujących się głównie z rent (ok. 9\%). Najniższy odsetek 
osób zagrożonych ubóstwem odnotowano natomiast w gospodarstwach domowych, których głównym źródłem utrzymania jest praca na własny rachunek - w grupie tej zagrożona ubóstwem skrajnym była co pięćdziesiąta osoba (ok. 2\%).

Ze względu na typ gospodarstwa domowego, grupy szczególnie zagrożone ubóstwem stanowiły rodziny wielodzietne oraz rodziny niepełne. W 2016 r. poniżej minimum egzystencji żyła co dwudziesta osoba w gospodarstwach małżeństw z 3 dzieci na utrzymaniu (prawie 5\%) oraz co siódma osoba w gospodarstwach małżeństw z 4 lub większą liczbą dzieci na utrzymaniu (14\%). Natomiast wśród osób tworzących rodziny niepełne wskaźnik zagrożenia ubóstwem skrajnym wyniósł niecałe 6\%. Należy jednak podkreślić, iż sytuacja rodzin niepełnych jest zróżnicowana - w przypadku samotnych rodziców z większą liczbą dzieci na utrzymaniu poziom zagrożenia ubóstwem był wyższy.

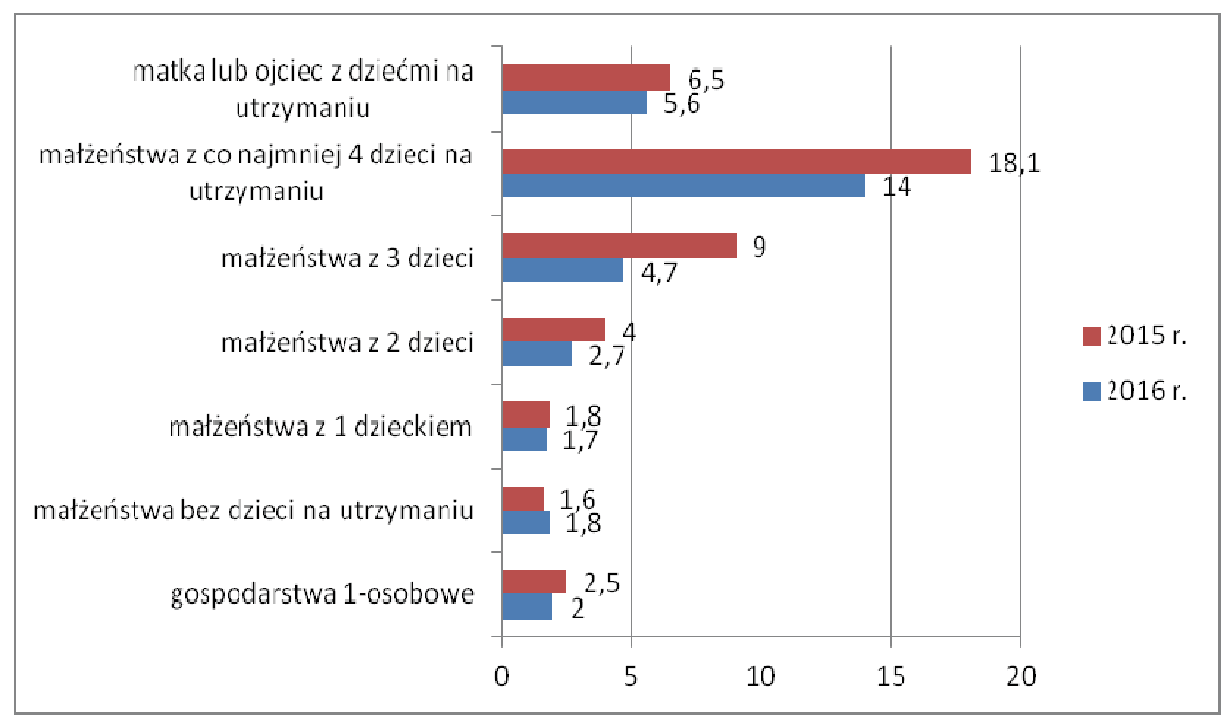

Rys. 2. Zasięg ubóstwa skrajnego w latach 2015-2016 w \% osób w gospodarstwach domowych wg typów gospodarstw domowych

Fig. 2. Extent of poverty in 2015-2016 in \% of households by type of households

Źródło: GUS, Badanie budżetów gospodarstw domowych, 2017.

Uwzględniając w analizach wiek mieszkańców Polski zauważyć można, że w porównaniu do lat ubiegłych, w 2016 r. wyraźnie zmniejszyły się różnice w zasięgu ubóstwa skrajnego pomiędzy poszczególnymi grupami wieku. Przy tym nadal najwyższą wartość stopy ubóstwa odnotowano wśród dzieci w wieku 0-17 lat (niecałe 6\%), natomiast najniższą wśród osób w wieku 65 lat i więcej (ponad 3\%).

Prawdopodobieństwo doświadczania biedy zwiększało również niskie wykształcenie głowy gospodarstwa domowego. Zagrożona ubóstwem skrajnym była co 8 osoba zamieszkująca gospodarstwa domowe z głową gospodarstwa posiadającą wykształcenie co najwyżej gimnazjalne, podczas gdy $w$ gospodarstwach $\mathrm{z}$ głową gospodarstwa z wykształceniem zasadniczym zawodowym problem ten dotyczył co 14 osoby, średnim co 37 osoby, natomiast z wykształceniem wyższym - mniej niż co setnej osoby. 
Tabela 3. Zasięg ubóstwa skrajnego w latach 2015-2016 (w \% osób) w gospodarstwach domowych wg poziomu wykształcenia głowy gospodarstwa domowego oraz wg wieku

Table 3. Range of extreme poverty in 2015-2016 (in \% of people) in households by level of education of head of household and by age

\begin{tabular}{|c|c|c|}
\hline Wyszczególnienie & 2016 & 2015 \\
\hline \multicolumn{3}{|c|}{ wg poziomu wykształcenia głowy gospodarstwa domowego } \\
\hline co najwyżej gimnazjalne & 12,4 & 16,5 \\
\hline zasadnicze zawodowe & 7,3 & 9,7 \\
\hline średnie & 2,7 & 3,6 \\
\hline wyższe & 0,8 & 0,6 \\
\hline \multicolumn{3}{|c|}{ wg wieku } \\
\hline 0-17 lat & 5,8 & 9,0 \\
\hline 18-64 lat & 5,0 & 6,2 \\
\hline 65 i więcej lat & 3,4 & 4,2 \\
\hline
\end{tabular}

Źródło: GUS, Badanie budżetów gospodarstw domowych, 2017.

W 2016 r. zasięg ubóstwa skrajnego na wsi był dwuipółkrotnie wyższy niż w miastach. Różnica ta jest szczególnie wyraźna, gdy sytuację na wsi porównuje się z sytuacją w największych miastach (500 tys. lub więcej mieszkańców). W skrajnym ubóstwie żyło w 2016 r. roku prawie 3\% mieszkańców miast (od ok. 1\% w największych miastach, do 4\% w miastach poniżej 20 tys. mieszkańców). Na wsi odsetek osób żyjących poniżej minimum egzystencji wyniósł $8 \%$.

W kontekście terytorialnych zróżnicowań zasięgu ubóstwa ważna jest również ocena tego zjawiska według województw. W 2016 r. najwyższą stopę ubóstwa odnotowano w województwie warmińsko-mazurskim, podkarpackim, lubelskim, świętokrzyskim oraz wielkopolskim (po ok. 8-9\%). Najniższą wartość wskaźnika ubóstwa skrajnego zaobserwowano natomiast w województwach: lubuskim, łódzkim, dolnośląskim, śląskim i mazowieckim (po ok. 2-3\%).

Problem ubóstwa musi być rozwiązany ze względu na zrównoważony i trwały rozwój. Nie ma możliwości implementacji takiej strategii w warunkach powszechnego niedostatku, a brak zaspokojenia podstawowych potrzeb zwiększa, a nie zmniejsza liczby oddziaływań człowieka na środowisko przyrodnicze. Ekonomiczny niedorozwój nie pozwala na zorganizowanie właściwego systemu ochrony i wykorzystania zasobów środowiska przyrodniczego. Trudno jest wymagać od biednych społeczeństw skutecznej realizacji zrównoważonego i trwałego rozwoju (Czaja, Becla, 2011). Ograniczenie ubóstwa i spójność społeczna to zarówno priorytet ekonomiczny jak i strategiczny cel polityki społecznej Unii Europejskiej (Tendera-Właszczuk, 2010). Zgodnie z art. 153 TFUE włączenie społeczne ma zostać osiągnięte wyłącznie w oparciu o współpracę pozaprawną otwartą metodę koordynacji (OMK) - podczas gdy art. 19 TFUE umożliwia UE podejmowanie działania w celu walki z dyskryminacją zarówno poprzez udzielanie ochrony prawnej potencjalnym ofiarom, jak i przez zapewnianie środków zachęcających.

Problemy ubóstwa dostrzeżono także przy redagowaniu strategii określających kierunki rozwoju Unii Europejskiej, a zwłaszcza Strategii Lizbońskiej, w której ograniczenie ubóstwa i wykluczenia społecznego zostało wskazane jako jedno z podstawowych zadań na przyszłość. Ocena rozmiarów pracy, jaką trzeba włożyć w te zadania, oraz wskazanie, w jaki sposób należy tą pracę wykonać, wymaga diagnozy ubóstwa we współczesnej Europie. 
Walkę z ubóstwem i wykluczeniem społecznym prowadzi się zarówno w Unii Europejskiej, jak i poza jej granicami, zgodnie z milenijnymi celami rozwoju ONZ, do których osiagnięcia zobowiązała się Unia Europejska i jej państwa członkowskie. Ponadto, w dniu 22 października 2008 r. Parlament i Rada Europejska podjęli decyzję, w której w art. 1 stwierdzają, że: „(...) w celu wspierania działań Wspólnoty w walce z wykluczeniem społecznym rok 2010 ogłasza się Europejskim Rokiem Walki z Ubóstwem i Wykluczeniem Społecznym". Główne cele i zasady przewodnie Europejskiego Roku Walki z Ubóstwem i Wykluczeniem Społecznym były następujące (Dz.U. L 298/20 z dn. 22.10.2008):

a) uznanie praw - uznanie podstawowego prawa osób dotkniętych ubóstwem i wykluczeniem społecznym do godnego życia i do pełnego uczestnictwa w życiu społeczeństwa,

b) wspólna odpowiedzialność i uczestnictwo - zwiększanie odpowiedzialności publicznej za politykę i działania w dziedzinie integracji społecznej, podkreślające zarówno zbiorową, jak i indywidualną odpowiedzialność w zwalczaniu ubóstwa i wykluczenia społecznego oraz znaczenie promowania i wspierania działalności w ramach wolontariatu,

c) spójność - propagowanie bardziej spójnego społeczeństwa poprzez uświadamianie korzyści płynących dla całego społeczeństwa, z którego wyeliminowano ubóstwo, wspierającego sprawiedliwy podział i w którym nikt nie żyje na marginesie,

d) zaangażowanie i konkretne działania - podkreślenie silnego zaangażowania politycznego UE i państw członkowskich na rzecz wywarcia decydującego wpływu na likwidację ubóstwa i wykluczenia społecznego oraz propagowania tego zaangażowania i działań na wszystkich szczeblach sprawowania władzy.

Innym kompleksowym podejściem do rozwiązania problemu ubóstwa i wykluczenia społecznego jest zyskująca w ostatnich latach coraz więcej zwolenników idea ekonomii społecznej. Do najważniejszych funkcji ekonomii społecznej, które pozwalają z optymizmem patrzeć na skuteczność tego rozwiązania instytucjonalnego w walce z ubóstwem i wykluczeniem społecznym, zalicza się [Kryńska 2009]:

- wprowadzenie na rynek pracy osób, które mają trudności z samodzielnym znalezieniem sobie na nim miejsca,

- tworzenie nowych miejsc pracy zwłaszcza dla osób zagrożonych społeczną marginalizacją,

- świadczenie usług socjalnych dla jednostek i wspólnot lokalnych (zwłaszcza tam, gdzie sektor publiczny i prywatny nie są w stanie zaspokoić potrzeb społecznych),

- integracja grup wykluczonych społecznie z rynkiem pracy.

\section{Podsumowanie}

Ubóstwo jest zjawiskiem powszechnym i choć w szczególności dotyczy państw rozwijających się, to jednak jest ono widoczne także w tzw. państwach rozwiniętych. Mimo wysokiego poziomu życia w krajach Unii Europejskiej, cześć osób w dalszym ciągu jest dotkniętych biedą. W grupie podwyższonego ryzyka znajdują się dzieci, a także osoby starsze, których w Europie przybywa.

Nie ma uniwersalnego rozwiązania umożliwiającego wyeliminowanie ubóstwa i wykluczenia społecznego w całej Europie, ale istnieje potrzeba wspólnego działania i wymiany doświadczeń. Ta właśnie idea leży u podstaw europejskiej strategii walki 
z ubóstwem i wykluczeniem społecznym. Walkę z ubóstwem i wykluczeniem społecznym prowadzi Unia Europejska zgodnie z milenijnymi celami rozwoju ONZ, do których osiagnnięcia zobowiązała się UE i jej państwa członkowskie.

Unia Europejska ogłosiła rok 2010 Europejskim Rokiem Walki z Ubóstwem i Wykluczeniem Społecznym. Miało to na celu zwrócenie uwagi na problemy i obawy ludzi, którzy zmagają się $\mathrm{z}$ problemem ubóstwa i wykluczenia społecznego oraz zainspirowanie wszystkich obywateli Europy, aby zaangażowali się $\mathrm{w}$ walkę $\mathrm{z}$ tym problemem.

\section{Literatura}

Czaja, S., Becla, A. (2011). Czterech jeźdźców ekologicznej zagłady we współczesnym świecie (Four Riders of Ecological Extermination in the Present World). W: B. Kryk (red.), Trendy i wyzwania zrównoważonego rozwoju, Szczecin, 35-49.

Dziennik Urzędowy Unii Europejskiej, Decyzja Parlamentu Europejskiego i Rady w sprawie Europejskiego Roku Walki z Ubóstwem i Wykluczeniem Społecznym (Decision of the European Parliament and of the Council on the European Year for Combating Poverty and Social Exclusion). Dz.U. L 298/20 z dn. 22.10.2008.

GUS. (2017). Sytuacja gospodarstw domowych w 2016 r. w świetle wyników badania budżetów gospodarstw domowych (The situation of households in 2016 in the light of the results of the household budget survey). Warszawa.

http://ec.europa.eu/eurostat/documents/2995521/7695750/3-17102016-BP-EN.pdf/30c2ca2d-f7eb-4849-b1e1b329f48338dc.

Konstytucja RP (Constitution of the Republic of Poland). Dz. U. 1997, nr 78, poz. 483.

Kryńska, E. (2009). Flexicurity w Polsce. Diagnoza i rekomendacje. Raport końcowy z badań (Flexicurity in Poland. Diagnosis and recommendations. Final report on research). Ministerstwo Pracy i Polityki Społecznej, Departament Rynku Pracy Warszawa.

Piątek, Z. (2010). Ekofilozofia (Ecophilosophy). Wyd. Uniwersytetu Jagiellońskiego, Kraków.

Podstawowe dane dotyczące zasięgu ubóstwa w Polsce w 2015 r. (Basic data on the extent of poverty in Poland in 2015) (2016). Materiał na posiedzenie Międzyresortowego Zespołu ds. Strategii 2020, Warszawa.

Poskrobko, B. (2011). Ekonomia zrównoważonego rozwoju w świetle kanonów nauki (The economics of sustainable development in the light of the canons of science). Wyższa Szkoła Ekonomiczna, Białystok.

Ratyński, W. (2003). Problemy i dylematy polityki społecznej w Polsce (Problems and dilemmas of social policy in Poland), t. 1, Warszawa.

Sutkowska, N., Kandefer K.. (2013). Problem ubóstwa w krajach Unii Europejskiej (The problem of poverty in the countries of the European Union). Zeszyty Naukowe UW MSC, 1(39), 37-58.

Szukiełojć-Bieńkuńska, A. (2008). Ubóstwo w Polsce na tle krajów Unii Europejskiej - podstawowe fakty i dane (Poverty in Poland against the background of the European Union countries - basic facts and data). Ekspertyza przygotowana w ramach projektu EAPN Polska - profesjonalny dialog na rzecz Europy Socjalnej, Warszawa.

Tendera-Właszczuk, H. (2010). Polityka społeczna krajów Unii Europejskiej po wschodnim rozszerzeniu (Social policy of the European Union countries after the eastern enlargement). Polskie Towarzystwo Ekonomiczne, Kraków.

Toczyski, W. (1991). Natura i kwestia ubóstwa (Nature and the question of poverty). OBS, Gdańsk-Warszawa.

Ustawa Prawo Ochrony Środowiska (The Environmental Protection Law). Dz. U. 2001, nr 62, poz. 627.

\section{Do cytowania / For citation:}

Biernat-Jarka A., Trębska P. (2018). Ubóstwo w Polsce i Unii Europejskiej a formy jego przezwyciężania w kontekście zrównoważonego rozwoju i doświadczeń UE. Problemy Rolnictwa Światowego, 18(1), 38-47; DOI: 10.22630/PRS.2018.18.1.3

Biernat-Jarka A., Trębska P. (2018). Poverty in Poland and the European Union and the Forms of Overcome it, in the Context of Sustainable Development and the EU Experience (in Polish). Problems of World Agriculture, 18(1), 38-47; DOI: 10.22630/PRS.2018.18.1.3 